\title{
A Study on the Perception of Students towards Educational Weblogs
}

\author{
Andrew K. LUI, Sheung-On CHOY \\ School of Science and Technology, The Open University of Hong Kong \\ Hong Kong SAR, China \\ e-mail: andrew.lui@computer.org,sochoy@ouhk.edu.hk \\ Yannie H.Y. CHEUNG \\ Department of Sociology, Chinese University of Hong Kong \\ Hong Kong SAR, China \\ e-mail: yanniec@cuhk.edu.hk \\ Sandy C. LI \\ Department of Education Studies, Hong Kong Baptist University \\ Hong Kong SAR, China \\ e-mail: sandyli@hkbu.edu.hk
}

Received: May 2006

\begin{abstract}
Weblogs are a popular form of easy-to-use personal publishing that has attracted millions of bloggers to share their personal thoughts, opinions, and knowledge on the web. The versatility of weblogs as a communication medium has attracted interests from educators. Educational applications of weblogs have so far included journals, e-portfolio, learning diaries, and logbooks. As in the case of other educational technologies, the perception of students is a determinant factor of whether weblogs are used in a way that elicits educational values. This paper investigates student perception towards the purposes of blogging. It reports an experience of introducing blogging tasks to third year computing students, and compares their perception with students not participating in the blogging tasks. A student perception model is proposed to explain the difference in the perception due to the experience in blogging. The paper concludes that mandatory use of weblogs in a course can gradually cultivate educationally sound perceptions in students despite of the observed misuse.
\end{abstract}

Key words: weblog, blogging, educational blogging, student perception, feedback model.

\section{Introduction}

There is a recent emergence of interest in the educational use of weblogs. Weblogs are web-based journals that are updated regularly, publicly accessible, containing short text and visual entries that are displayed in reverse chronological order. Blogging, which refers to the act of maintaining a weblog, have caught the imagination of many academics about its potential to promote effective learning. From a cognitive development perspective, the journalistic feature of weblogs encourages personal reflection, critical thinking, 
and rigorous writing composition. Weblogs also force bloggers to anticipate confrontational views, to formulate arguments, and to develop greater confidence in holding an opinion. The commentary facility built into weblog software supports knowledge coconstruction, which is achieved through a conversational interaction between peer students and teachers. Knowledge is categorized, archived, and shared in weblogs in the form of text, graphics, hyperlinks, and feedbacks. Example applications of educational weblogs include individual writing journals, collaborative journals, teacher journals, eportfolios, news reports, learning diaries, and research logbooks.

Student perception is an influential factor in the successful adoption of educational technology. There is no inherent pedagogical value in weblogs. To get any educational value out of weblogs, the students must pursue educationally sound behaviors such as participation and interaction. The decision on the acceptance of weblogs and the way that weblogs are used is determined ultimately by student perception. According to the Theory of Reasoned Action (Fishbein and Ajzen, 1975), human behaviors are shaped by perception. The Technology Acceptance Model (Davis, 1989) further suggested that the perceived effectiveness of a technology for the tasks at hand determines the acceptance of the technology. O'Malley and McCraw (1999a) added that the perceived effectiveness of an educational technology is dependent on the perceived characteristics of the technology and the characteristics and background of students.

This paper describes a study on student perception towards educational blogging. The context of the study is a trial incorporation of weblogs in a third year computing course at the Open University of Hong Kong. The main objective of the study is to investigate the perception of students towards educational weblogs after one year of blogging tasks. The perceived purpose of blogging was the focus of the study and therefore a typology of blogging purposes was developed. The paper introduces an adaptation of the Student Perception Model (O'Malley and McCraw, 1999a) according to the proposition that the act of blogging offers opportunities to discover new aspects of blogging usefulness and to engender a change of perception. There are supportive evidences found in the study to show that students had gained greater awareness of the purposes of educational weblogs after one year of blogging tasks.

The paper is structured as the following. The next section provides an overview of weblogs and describes the versatility and impact of weblogs. The educational use of weblogs and the theories concerning student perception towards educational technology are reviewed. Section 3 describes the research objectives and research methods. The results and discussions of the research are given in Section 4, and Section 5 concludes this paper with comments about future work.

\section{Background}

\subsection{Overview of Weblogs}

Weblogs belong to a form of web-based publication consisting primarily of entries (articles, news items, or other forms of write-ups), which are posted in reverse chronological 
order. Weblog entries invariably contain hyperlinks to other web resources, and they allow readers to leave comments that will be displayed with the entries. The simplicity of the mechanism of blogging, the scope for online interactivity and collaboration, and the availability of easy-to-use tools (weblog software) combined to propel weblogs as a popular communications tool and personal publishing means.

Although the interface of weblogs varies with the types and intended uses, there are more similarities than differences. The first page (also called the home page) of a weblog usually provides an overview of the weblog, which contains (see Fig. 1 for illustration):

- a number of latest entries shown in reverse chronological order;

- a list of latest responses received from readers;

- a search box for readers to look for particular contents of the weblog; and,

- a list of links to monthly archives or archives by entries category.

The single entry view of the weblog (see Fig. 2) is shown after clicking on the link to a particular entry. It shows the entry content, all the comments given by readers on that entry, and a form that lets the current reader to leave a comment. The archive view of the weblog allows readers to easily navigate weblog entries by category or by date.

A weblog is a web-accessible place that one creates a post with the conscious aim of sharing with its readers, inviting feedbacks and initiating conversations. Therefore, the most basic activities associated with a weblog are writing, reading and commenting. A weblog with its ability to let readers leave comments on each post creates the feel of a conversation. Comments made to a post are time-stamped, displayed chronologically, and identified by the reader's name and perhaps a link to their weblogs.

Trackback is another key activity associated with a weblog, though many beginners are not of aware of this technology. Trackback enables a weblog to inform another weblog that an entry of the former is mentioning an entry of the latter. Upon approved by the latter, a link to the entry of the former weblog will be included in the entry of the latter weblog. To send a trackback request to a weblog entry, one needs to put the trackback Universal Resource Locator (URL) into the allotted spot in the weblog software before publishing the entry. Then weblog software will autonomously communicate to build a link from the original entry to the new entry. Trackbacks and comments to an entry are placed along with the entry contents so that readers can read responses of others and the related entries by other bloggers.

To set up a weblog, bloggers can choose between two kinds of weblog software. The first kind is hosted weblog software that resides on a web server of a service provider. Bloggers access their weblogs using a web browser to point to a specific URL. Various web interfaces are provided for posting an entry, updating the interface of a weblog, and setting configurations. There are many service providers that offer blogging service free of charge. Another kind of weblog software resides on the blogger's own web server. The blogger is responsible to download and install a piece of software, and in return the blogger has greater control over the design and publishing means of the weblogs. Usually a database is used to support the backend storage so that weblog content can be efficiently archived and searched. 


\section{Recent Steven In Computing Education}

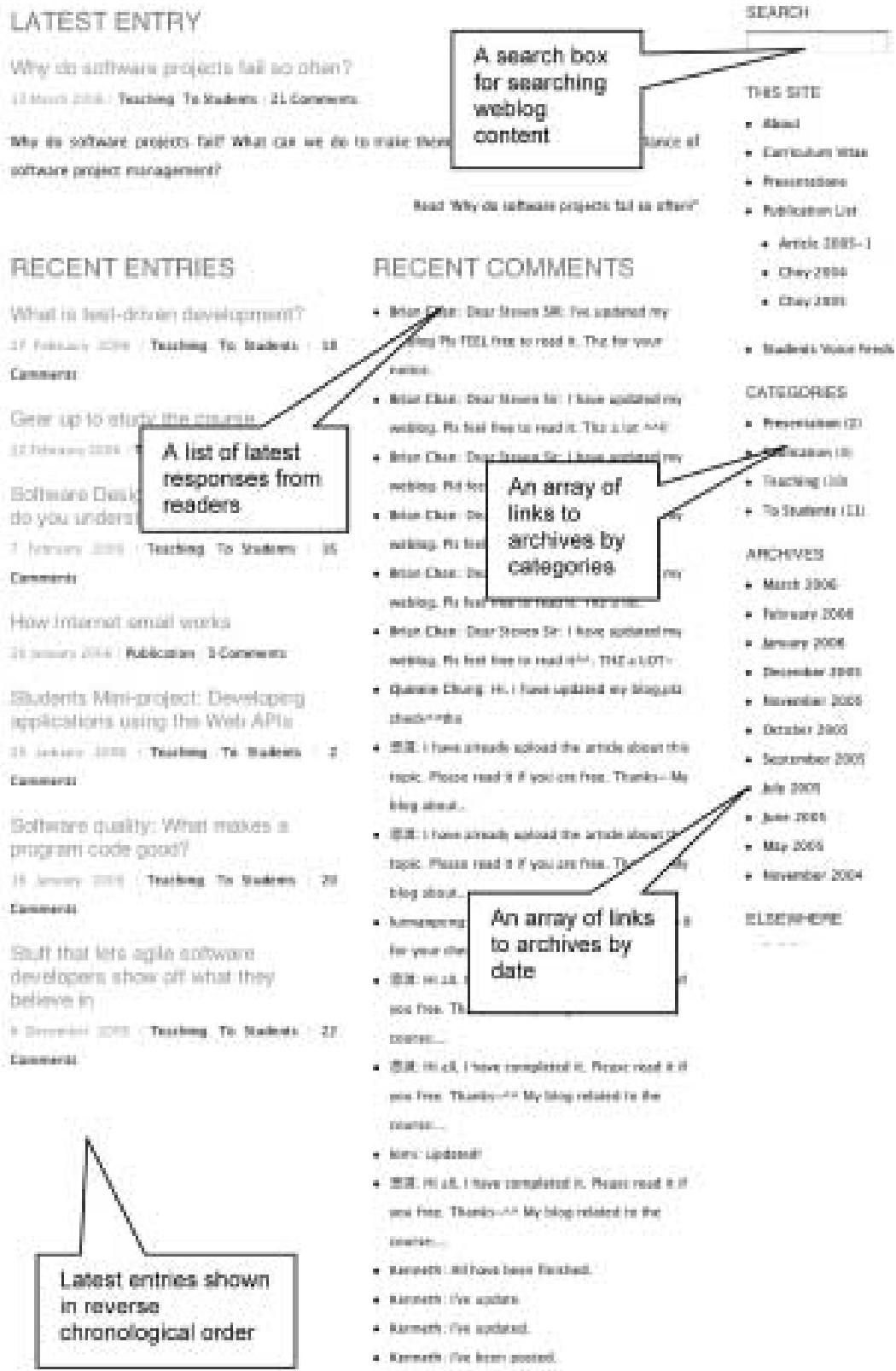
- Aeominarar

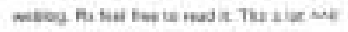

Fig. 1. The home page view of a weblog showing the basic interface. 


\section{Pecent Steven In Computing Education}

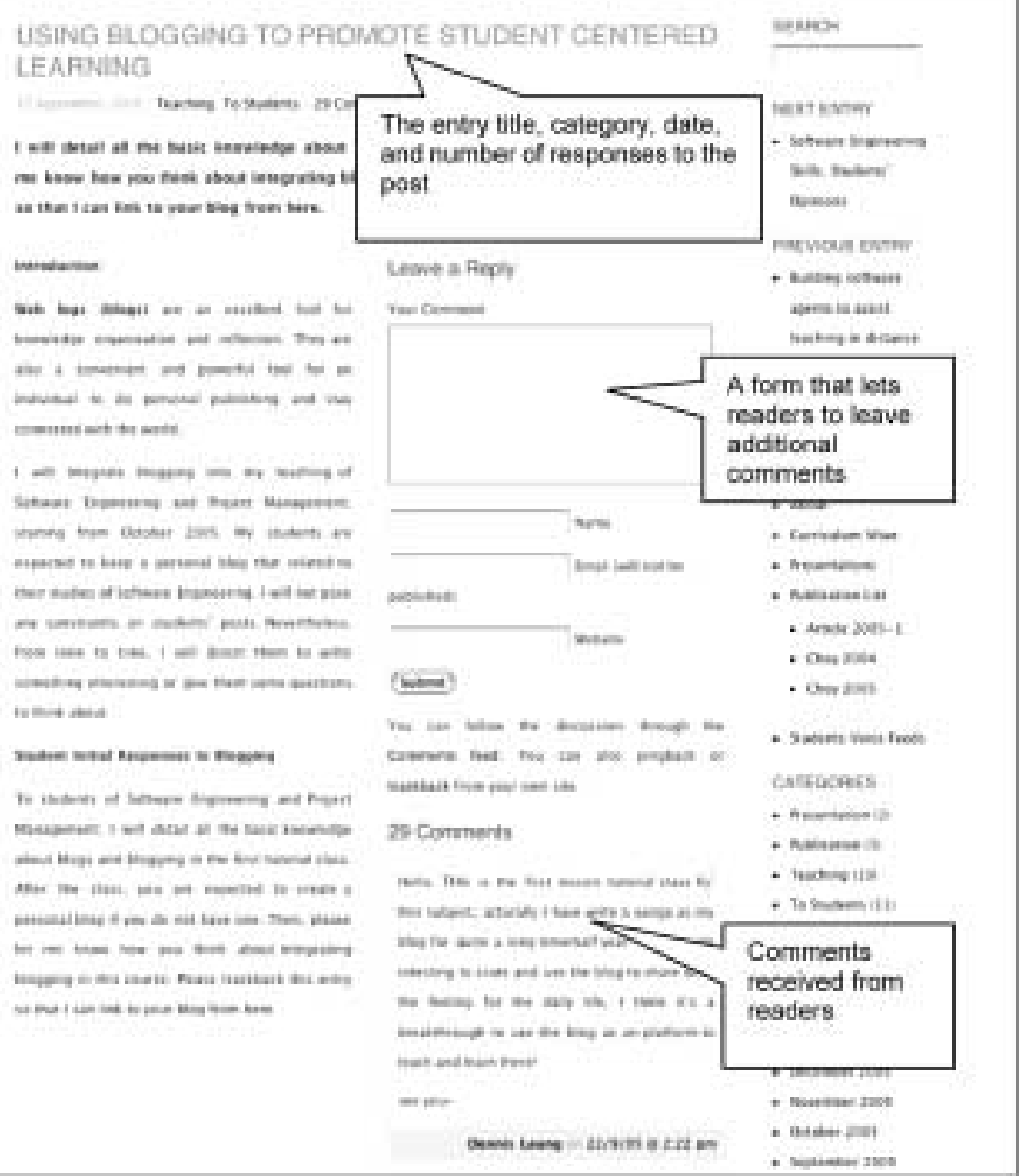

Fig. 2. The single-page view of a weblog showing the basic elements of a post.

\subsection{Versatility and Impact of Weblogs}

Weblogs as a phenomenon have already exerted significant impact to the world. According to Technorati (www . technorati.com), an Internet search engine for weblogs, there are over 30 million weblogs as of May 2006 and the rate of increase is at a staggering 75 thousands each day. A continuous research work by the Pew Internet Project estimated that 25 percent of netizens read weblogs regularly, and over 1 million new entries are written for their daily consumption. Although only a minority of weblogs has a reasonable readership, such figures still represent an impressive penetration rate. In the weblog world, consumers of information are also producers of information, and a new form of 
authorship is created that emphasizes connections to the community, discourses, and processes (Wrede, 2003). With a broadcasting capability that can potentially reach every corner of the Internet, weblogs enable amateur journalism to attain unprecedented influence. Past events like the 911 bombing and the US-Iraq war were reported in weblogs in a personal, raw, and direct perspective that would never make it through the mainstream media (Rainie et al., 2002; Lampa, 2004). Every blogger is potentially an opinion leader, and the imagination of having a worldwide audience, the supportive comments, citations in other blogs and other media further reinforce the enthusiasm in blogging (Jacobs, 2003).

Weblogs as a technology has changed how we communicate and relate to the world. Mejias (2004) remarked that rapidly appearing communication technologies such as weblogs can completely alter the media space. There are diverse views about the change in online social interactions brought about by weblogs. Merlow (2004) saw the emergence of a new form of social interactions based on a massively distributed, all-topic encompassing, and fully connected conversation. Merlow distinguished the roles of various blog hyperlinks in the conversation: permalinks enable distributed conversation between two blogs; blogrolls allow group dialogue and opportunities to establish ties with bloggers with similar interests; comments support direct interaction between readers and writers; and trackbacks provide social awareness beyond the scope of a blog. Herring et al. (2005) applied social network analysis techniques to discover that massively-interconnected weblog conversation is however the exception rather than the norm. The so-called A-list weblogs, which are the most cited and read ones, do exist but they comprise of less than $15 \%$ of all active weblogs. Nearly half of the weblogs contain no links to other weblogs, reflecting the fact that many weblogs are used for posting personal diaries or updating friends in the real world (Perseus, 2003). The vast majority of weblog communities exists in the form of clusters sharing a common topic, and also exists in weblog pairs between which indicate a one-to-one relationship (Herring et al., 2005). Efimova and Hendrick (2005) pointed out that weblog communities develop from the connections between weblogs, despite that there is no common space and fixed membership. Clearly a range of highly diversified social structures have been emerged out of blogging, which reflects the paradoxical nature of weblogs: a personal space and a community space coexist in a virtual environment, in which bloggers engage in conversations with self and others simultaneously (Efimova and de Moor, 2005).

The impact of weblogs on content creation, information dissemination, and knowledge management is also notable. O'Donnell (2005) viewed that blogging is a form of personal publishing that cultivate a unique kind of writers characterized by adhering to a structural yet flexible layout, connecting to a network of relationships, and involving in a hyperspace of web resources. Blood (2002) further stressed that linking to the original and reference materials are paramount to weblogs, because hyperlinks can expand the frontier of the content space and bring relevant information to the reader. The tendency to have numerous links is favorable to attain higher ranking in search engines, and therefore weblogs provide an attractive method to disseminate information for business and event organizers. The ease of use characteristic has enabled instructors with minimal computing skill to disseminate information in courses, and also staff to store and 
share information with other parts of an organization. Another tendency of weblogs is an accumulation of information, and the availability of weblog search engines can turn the archived information into knowledge (Williams and Jacobs, 2004). Roll (2004) suggested that in the context of knowledge management, weblogs can serve as a personal information repository, a journal of thoughts and ideas, a repository of feedbacks and comments, and an online presence. According to Guidewire Group, nearly 90 percent of US corporations have already set up weblogs or intended to do so, quoting both internal communications and external recognition as the reasons (Guidewire Group, 2005). The academic communities are also fast embracing blogging, and prime examples include the Harvard Law blogs (http://blogs.law.harvard.edu) and the Stanford law blogs (http://cyberlaw.stanford.edu).

\subsection{Educational Use of Weblogs}

In recent years, the adoption of technologies in education has accelerated to a relentless pace. Barely little intervals passed between the arrivals of new technologies, which all claim to bring revolutions to education. There is less and less time to investigate, reflect, and assimilate the technologies to bring true values in teaching and learning. Weblogs represent the latest communication technology to catch the fascination of educators after emails, discussion forums, and mobile learning. Weblogs and other communication technologies, especially discussion forums, share many similarities. They are both communication technologies; text is the predominant medium of communication; the required computing skill is minimal; and perhaps most significantly, they are both multiple affordances. Many of the potential learning benefits of discussion forums also apply to weblogs such as opportunities for active learning, collaborative learning, increased higher-level thinking, and flexibility in course delivery (Wu and Hiltz, 2004). Ferdig and Trammell (2004) provided a detailed discussion of the learning benefits of weblogs from the perspective of social constructivism

Many educational applications of weblogs were in subject areas that traditionally relied on journal writing (Williams and Jacobs, 2004). Huffaker (2005) described a number of instances where weblogs are used to improve writing and journalistic skills in classrooms of third graders to high school students. Stiler and Phillko (2003) applied weblogs for improving journaling skills of pre-service teachers.

Weblogs have also been applied in other educational purposes. Forster and Tam (2004) supplemented classroom teaching with blogging for MBA students to develop business language and communication skills. Wagner (2003) described using weblogs as student diaries and learning logbooks. E-Portfolio is gaining momentum in academic communities as a tool to promote student-centered learning and career development, and (Tosh and Werdmuller, 2004) discussed the application of weblogs for e-portfolio development. Other applications include web presence for courses (i.e., course blogs) and a research logbook. 


\subsection{Student Perception of Educational Technologies}

Student perception towards educational technologies is a well researched topic, based on the premise that perception determines behaviors. Based on the earlier work of Everett Rogers on the Model of Diffusion of Innovation, O'Malley and McCraw (1999a) described the Student Perception Model suggesting that the perceived effectiveness of a technology such as online learning is contributed by three factors: the prior educational condition, characteristics of students, and perceived characteristics of the technology. Students will then act in accordance to the perceived effectiveness of the technology. According to the Technology Acceptance Model proposed by Davis, the acceptance of a technology depends on the perceived usefulness and perceived ease-of-use (Davis, 1989). Perceived usefulness is the level of belief that a technology can enhance the performance in doing a particular task, and perceived ease-of use relates to the amount of effort required to learn and to perform a task (Cheung et al., 2004). The Theory of Reasoned Action also stressed the importance of perception in determining behaviors, but also acknowledged the role of the opinions of peers and other important people.

In case of a versatile technology that enables multiple purposes, student perception can become differentiated towards each facet of the technology. Weblogs is such a versatile technology that offers bloggers with many affordances, including immediateness, global-ness, connected-ness, engaged-ness, and authoritativeness (Forster and Tam, 2006). The affordance of weblogs refers to the inherent or perceived possibilities of interacting with the weblogs. If a multiplicity of affordances is available, only the affordances perceived to be relevant and useful will be chosen (Stoffregen (2003) cited in (Forster and Tam, 2006)). The first three affordances, immediate-ness, global-ness, and connectedness are inherited from the Internet as a result of weblogs being an Internet application. Immediate-ness refers to the immediate availability of a weblog entry after it is posted; global-ness means that the weblog entry is available to everyone in the Internet, including acquaintances and strangers; connected-ness describes the hyperlink integration with any web resource; engaged-ness refers to the interactions between bloggers and readers; and authoritativeness describes the control of the bloggers over the content and style of their weblogs.

Practitioners of educational technology find that many students do not take full learning benefits available to them (Wozniak and Silveira, 2004). Clearly, student perception has played a role here in determining not to pursue educationally sound behaviors such as participation and interaction. There ought to be diversified perceptions towards an educational technology, due to the natural variations in the student background. Williams and Jacobs (2004) integrated an assessment linked blogging component in a MBA course. About half of the students elected to participate and made at least five meaningful contributions about the course content. They generally agreed that weblogs assisted their learning and contributed to meaningful intellectual interactions. A considerable proportion of the non-participants considered the marks not worth the effort. A student, when asked to elaborate the choice, considered that reading weblogs of other students was more valuable. Such lurkers had undoubtedly given up the possibilities of in-depth interactions 
and discussions, but they could still gain through witness learning (Hulsmann, 2003). Whether lurking is an educationally sound behavior depends on perspective of judgment (Preece et al., 2004). Lurkers have simply chosen to invoke one of the possible purposes of weblogs according to their perceptions.

There are at least two approaches to getting educational values from weblogs: regulating the behavior and changing the perception. A weakness of the first approach is that undesirable behaviors still often occur, when students are guided by their perceptions to circumvent the regulations. A prime example is the use of mandatory participation (with possible implications on assessment) to force students to use online discussion forums. It was often found that the postings were of little values because they were written to satisfy the requirement, not to genuinely involve in an online discussion. In addition, (Knobel and Lankshear, 2003) lamented that many mandatory school weblogs showed a lack of effort in writing and development, for the vitality of blogging stifled by an absence of genuine purpose and meaningful task. E-moderation is a more agreeable and effective method that incorporates the two approaches. In e-moderation, an instructor is required to manage four areas of moderation, which include designing academic activities, developing a learning community, managing course administrative matters, and supervising technological functions (Berge, 1995). The objective is to encourage students to interact with the educational technology, and in doing so, to create the opportunities that the usefulness of the technology will change the perception.

\section{Research}

\subsection{Overview}

The aim of this research is to study the perception of students towards the effectiveness of weblogs. The research has adapted the Student Perception Model of (O'Malley and McCraw, 1999b) and developed a variation incorporating feedback for this study. Fig. 3 shows the components in the Feedback Model of Student Perception towards Weblogs.

This variation of the original Student Perception Model has taken into consideration that blogging experience provides the opportunities that the perception may be changed, due to a possibly discovery of the usefulness of the technology. This feedback mechanism exists regardless of the cause of blogging, whether the students are coerced, encouraged, or left to make an autonomous decision. An example is that a student blogged only because of a mandatory requirement of a course. The student did not blog in a way that got much educational value, but opportunities were still there that the student would discover some useful purposes about blogging and the perception would change as a result.

Given that the purpose of blogging is a focal point in this study, a typology of blogging is developed to provide a framework of analysis. Weblogs afford a versatile range of purposes and a typology can provide a structure. According to literature review and antidotes, the common purposes and their key aspects of educational weblogs have been developed.

The common purposes of educational weblogs include the following: 


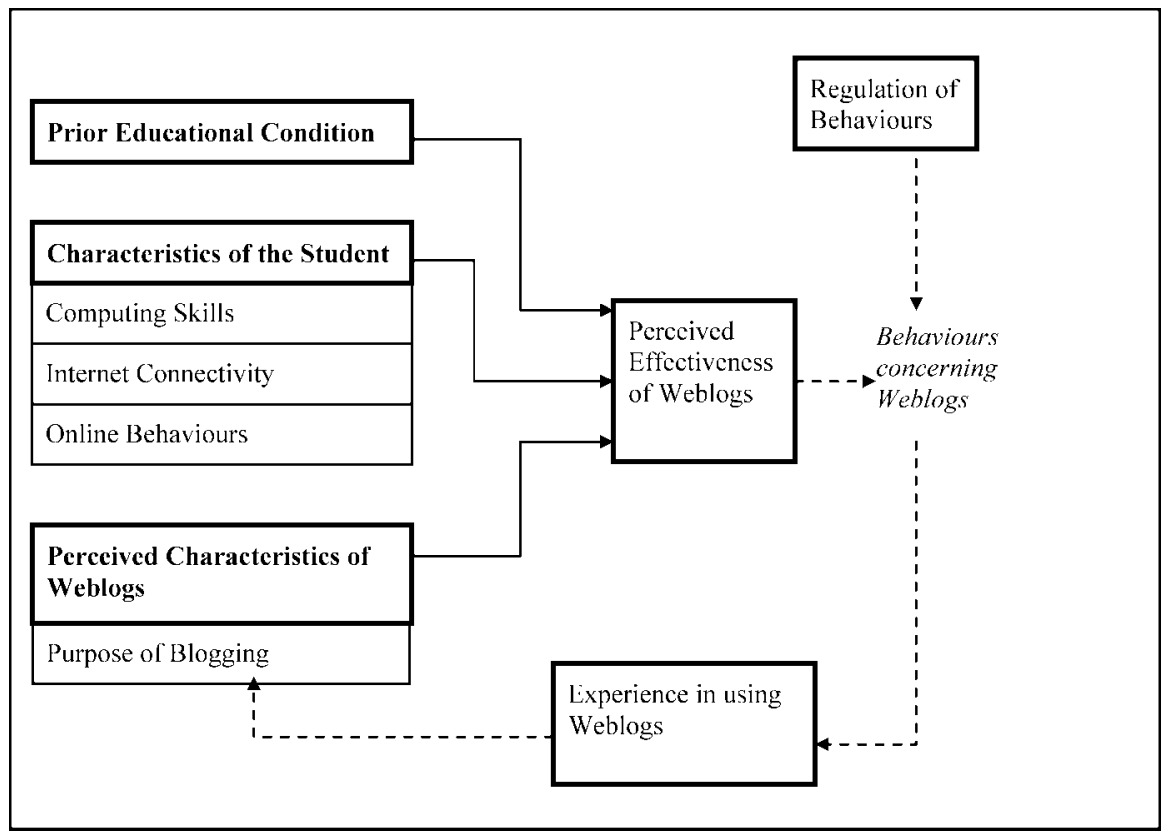

Fig. 3. Feedback model of student perception towards weblogs.

1. Logbooks as records of research activities, projects, or assessment.

2. Learning diaries as records of reflections of learning experience.

3. Portrait as a means to tell the world about me.

4. Electronic portfolio as a purposeful collection of my representative work and ideas.

5. Place of dialog where communication takes place.

6. Place of file sharing where electronic files are uploaded and download.

7. Place of collaboration where peer students work together.

8. Source of information where information and news are obtained.

The hypothetical key aspects of educational weblogs include the following:

1. Personal.

2. Communication.

3. Pedagogical.

Table 1 shows the loadings of the three aspects in each of the purposes of educational weblogs.

Based the above literature review and conceptual development, the objectives of this research study include the following:

1. To investigate the student perception towards the typology of purposes of blogging.

2. To compare the difference of student perception about the purposes of blogging between students with one-year educational blogging experience and those with no experience. 
Table 1

Common purposes of educational weblogs and their contributions to blogging

\begin{tabular}{llll}
\hline \multirow{2}{*}{ Purposes } & \multicolumn{3}{c}{ Contributions } \\
\cline { 2 - 4 } & Personal & Communication & Pedagogical \\
\hline Logbook & High & Low & Medium \\
Learning Diaries & High & Low & Medium \\
Portrait & High & Medium & Low \\
Electronic Portfolio & High & Medium & Medium \\
Place of Dialog & Low & High & Medium \\
Place of File Sharing & Low & High & Low \\
Place of Collaboration & Low & Medium & High \\
Source of Information & Low & Medium & High \\
\hline
\end{tabular}

\subsection{Research Method}

The subject of our study was third-year undergraduate students in a year-long computing course - MT356F Software Engineering and Project Management. The class has 28 students and one instructor, and has regular lectures and laboratory sessions during the course study. At the beginning of the course, the instructor used a three-hour laboratory session to introduce blogging as a way to improve student learning. The presentation included the following items: an overview of weblogs, example usage of weblogs, common blogging software, how to set up and maintain a weblog, and blogging jargons such as entry, comments, entry categories, trackbacks, and blogrolls.

The students were required to own individual weblogs for study purpose. They were free to use their existing weblogs or set up a new one. The instructor then made all student weblogs known to the class by posting all the weblog URLs in the course website. Students were made to blog to gain experience in blogging. Each month students were given a course related issue to think about, and they were required to write a weblog entry to share their views. The work in the weblogs contributed towards part of the course assessment.

With reference to the typology developed, the tasks were designed to use weblogs as an information sharing place. The weblogs were where student work was posted by students and assessed by teachers. There was a possibility of a student developing it into some sort of logbook and e-portfolio. The manifestation of other purposes of blogging was not anticipated.

The course study lasted for 13 weeks in the first semester and another 13 weeks in the second semester. In the last week, students were asked to answer a questionnaire about their perceptions of blogging and their background. The questionnaire is given in the Appendix. At the same time, students from another computing course MT258F Computer Programming and Problem Solving were asked to fill in the questionnaire. These students did not participate in educational blogging and they served as the control group. 


\section{Results and Discussions}

\subsection{General Characteristics of the Sample}

The sample has a size of 22 students from MT356F and 18 students MT258F. The students from MT258F, who did not take part in the blogging tasks, served as the control group in some items of study. Among these 40 respondents, $67.7 \%$ of them are males and $32.4 \%$ are female students. The average age of the sample is 22.7 years.

\subsection{Typology of Blogging Based on Principal Component Analysis}

The typology of blogging is derived from eight questionnaire items from the survey. Factor analysis was used to reduce the items into three factors. Principal Component Analysis was selected as a method for reducing the number of variables. The strategy of varimax with Kaiser Normalization was employed to obtain a clear pattern of loadings. Factor analysis result was generated from all reported cases of the dataset.

The first factor is marked by high loadings on the personal usage items, the second factor is marked by high loadings on the communication usage items, and the last factor is marked by high loadings on pedagogical usage. We would thus conclude that usage of blogs, as measured by our questionnaire, is composed of those three aspects; hence we have arrived at a classification of the variables, i.e., personal usage, communication usage and, pedagogical usage. The classifications of the questionnaire items are shown in Table 2 .

\subsection{Differences in Perceptions Towards the Purposes of Blogging}

A comparison of the MT356F and the control group respondents' perceptions towards the purposes of blogging has been made according to the three factors generated from the results of factor analysis. The perceptions of the respondents towards blog usage were ranked in three categories, Low, Medium and High.

The results indicate that a one-year experience of educational blogging can improve the student understanding towards all purposes of blogging. Students had become aware of more purposes of blogging, especially in the pedagogical and communication aspects. On the other hand, the results also show that the control group students are especially ignorant of the personal aspect of blogging.

The first factor, Personal Usage, both MT356F and Control group respondents assign medium rankings to blogs for personal usage (41.4\%) If we look at the results separately, MT356F respondents report higher perceptions than those of the control group. $69.2 \%$ of MT356F respondents give blogs for personal usage medium rankings. $62.5 \%$ of control group respondents report low level of perception towards webblogs for personal usage (Table 3).

The second factor, Communication Usage, 44.8 of respondents from both MT356F and Control group respondents assign medium rankings to blogs for collective file sharing purposes. But if we look at MT356F and the control group separately, we find that 
Table 2

Classifications of the questionnaire items with respect to blogging typology

\begin{tabular}{|c|c|}
\hline \multirow{2}{*}{ Perception of Purpose } & Factor One (Personal) \\
\hline & Remarks \\
\hline Logbook & where I store any data, information and thoughts \\
\hline Diary of Learning & where I peep personal reflections and feelings of the learning experience \\
\hline Means of expressing myself & where I tell the world who I am \\
\hline Electronic portfolio & where I purposely manage a collection of my representative work and ideas \\
\hline \multirow{2}{*}{ Perception of Purpose } & Factor Two (Communication) \\
\hline & Remarks \\
\hline Place of Dialog & where communication takes place \\
\hline Place of File Sharing & where electronic files are made available in the web \\
\hline \multirow{2}{*}{ Perception of Purpose } & Factor Three (Pedagogical) \\
\hline & Remarks \\
\hline Place of Collaboration & where I work together with peer students \\
\hline Source of Information & where others obtain relevant information \\
\hline
\end{tabular}

more control group respondents (50\%) give medium ranking to blogs for file sharing than those of MT356F (38.5\%). If we further compare the high rankings, 38.5\% of MT356F respondents tend to use blogs as means of web resource sharing than those of the control group (Table 4).

The third factor, Pedagogical Usage, half of the respondents of both M356F and control group give medium level to rank blogs for pedagogical use (50\%). $30.8 \%$ of MT356F respondents assign high rankings to the third factor (Table 5).

\subsection{Perception of Students with Respect to Online Behaviors}

This and the next part of the study is not central to the objectives, but it is included to provide a background about the characteristics of the students. The result shows that

Table 3

Differences in personal usage of blogs between M356F and the control group

\begin{tabular}{llrrr}
\hline & & MT356F & Control & Total \\
\hline \multirow{2}{*}{ Personal Usage } & Low & $7.7 \%$ & $62.5 \%$ & $37.9 \%$ \\
& Medium & $69.2 \%$ & $18.8 \%$ & $41.4 \%$ \\
& High & $23.1 \%$ & $18.8 \%$ & $20.7 \%$ \\
\hline & Total & $100.0 \%$ & $100.0 \%$ & $100.0 \%$
\end{tabular}


Table 4

Differences in communication usage between M356F and the control group

\begin{tabular}{lllll}
\hline & & MT356F & Control & Total \\
\hline \multirow{2}{*}{ Communication Usage } & Low & $23.1 \%$ & $31.3 \%$ & $27.6 \%$ \\
& Medium & $38.5 \%$ & $50.0 \%$ & $44.8 \%$ \\
& High & $38.5 \%$ & $18.8 \%$ & $27.6 \%$ \\
\hline & Total & $100.0 \%$ & $100.0 \%$ & $100.0 \%$ \\
\hline
\end{tabular}

Table 5

Differences in pedagogical usage between M356F and the control group

\begin{tabular}{llccc}
\hline & & MT356F & Control & Total \\
\hline \multirow{2}{*}{ Pedagogical Usage } & Low & $15.4 \%$ & $33.3 \%$ & $25.0 \%$ \\
& Medium & $53.8 \%$ & $46.7 \%$ & $50.0 \%$ \\
& High & $30.8 \%$ & $20.0 \%$ & $25.0 \%$ \\
\hline & Total & $100.0 \%$ & $100.0 \%$ & $100.0 \%$ \\
\hline
\end{tabular}

students are generally passive in making contribution to an online community, despite that they regularly use the web to maintain relationships and to enjoy entertainment.

In this study, 19 questionnaire items are used to measure online behaviors of the respondents. We have questionnaire items measuring respondents' general online behavior (Table 6). We find that most of the respondents $(67.5 \%)$ go to the web for leisure and entertainment everyday. The Internet is a source of reading news and gossips everyday. Only $2.5 \%$ of the respondents do not go to the web for news and gossips. Almost half of the respondents seek academic information from the Internet everyday. The usage of messaging tools, for example, MSN/ICQ is common among the respondents. The majority of the respondents $(80 \%)$ reported that they use these tools on a daily basis. $57.5 \%$ of the respondents reported that they visit discussion forums and read postings every day. $45 \%$ of the respondents reported that they contribute to the discussion forums occasionally.

Self perception of the respondents in the virtual reality is another concern of this study. Four items were used to measure how the respondents perceive their computing skills and identities in the virtual reality (Table 7). $40.7 \%$ of the respondents consider themselves capable of managing their personal computers. 53.1\% the respondents report that they are confident in using computers to browse the web. The respondents were asked to compare the virtual world with the real world. $53.2 \%$ of the respondents disagree with the questionnaire statement "I enjoy the social life in the virtual world more than in the real world". $37.5 \%$ report "Neutral" regarding the statement. Only $9.4 \%$ of the respondents agree with the statement. While being asked about whether "The virtual world interests me more than the real world", $54.9 \%$ of the respondents disagree with the statement. $35.5 \%$ remain neutral. $9.7 \%$ of the respondents agree with the statement. 
Table 6

Respondents' general online behaviors

\begin{tabular}{lcccc}
\hline Questionnaire Items & Always (\%) & Sometimes (\%) & Occasional (\%) & Never (\%) \\
\hline Leisure and entertainment every day. & 67.5 & 25.0 & 7.5 & 0 \\
News and gossip every day. & 42.5 & 22.5 & 32.5 & 2.5 \\
Academic information every day. & 17.5 & 50.0 & 30.0 & 2.5 \\
$\begin{array}{l}\text { MSN/ICQ (or any messaging tool) every } \\
\text { day. }\end{array}$ & 80.0 & 15.0 & 5.0 & 0 \\
$\begin{array}{l}\text { Discussion forum and read postings every } \\
\text { day. }\end{array}$ & 57.5 & 25.0 & 15.0 & 2.5 \\
$\begin{array}{l}\text { Discussion forum and post messages every } \\
\text { day. }\end{array}$ & 17.5 & 30.0 & 45.0 & 7.5 \\
\hline
\end{tabular}

Table 7

Respondents' self perception in the virtual reality

\begin{tabular}{lccccc}
\hline Questionnaire Items & $\begin{array}{c}\text { Strongly } \\
\text { disagree }(\%)\end{array}$ & $\begin{array}{c}\text { Disagree } \\
(\%)\end{array}$ & $\begin{array}{c}\text { Neutral } \\
(\%)\end{array}$ & $\begin{array}{c}\text { Agree } \\
(\%)\end{array}$ & $\begin{array}{c}\text { Strongly } \\
\text { agree }(\%)\end{array}$ \\
\hline $\begin{array}{l}\text { I am confident in managing my personal } \\
\text { computer }\end{array}$ & 12.5 & 15.6 & 31.3 & 21.9 & 18.8 \\
$\begin{array}{l}\text { I am confident in using a computer to browse } \\
\text { the web }\end{array}$ & 12.5 & 12.5 & 21.9 & 25.0 & 28.1 \\
$\begin{array}{l}\text { I enjoy the social life in the virtual world } \\
\text { more than in the real world }\end{array}$ & 18.8 & 34.4 & 37.5 & 6.3 & 3.1 \\
$\begin{array}{l}\text { The virtual world interests me more than the } \\
\text { real world }\end{array}$ & 19.4 & 35.5 & 35.5 & 9.7 & 0 \\
\end{tabular}

\subsection{Perception of Students with Respect to Blogging}

In this study, nine questionnaire items were used to measure the frequencies of blogging activities. On average, the respondents own 2 blogs or online diaries. They spend 4.83 hours per week on visiting blogs. On average, the respondents made 1.94 comments every week. They contribute 2.47 postings on their personal blogs every week.

Social interaction is an aspect most vital to blog users. In this study, questionnaire items on social interaction in the real world and the virtual reality have been asked (Table 8 ). We find that the respondents make an average of 4.07 through blogging. They make an average 13.68 friends by mean of other forms of web interaction, for example, MSN, ICQ or web pages. While being asked about the number of net-friends the respondents have never met in the real world, the average is 8.22 people. While being asked about the number of friends that the respondents meet regularly in the real world, we find that on average, the respondents have 9.77 friends that they often meet in the real world. Regarding frequency of going to the web everyday, we obtain an average of 8.42 hours per day. 
Table 8

Means and standard deviations of respondents' blogging activities

\begin{tabular}{lrr}
\hline Questionnaire Items & Mean & S.D. \\
\hline Number of personal blogs or online diaries owned by the respondents & 2.00 & 1.693 \\
Number of blogs which you regularly visit (visit at least once every week) & 4.83 & 4.836 \\
Number of comments you write to blogs every week & 1.94 & 3.654 \\
How many postings do you write on your personal blog(s) per week? & 2.47 & 2.185 \\
How many friends you have made through blogging? & 4.07 & 6.411 \\
How many friends you have made through other web interaction & 13.68 & 17.333 \\
(e.g., MSN/ICQ or web pages)? & 8.22 & 19.506 \\
How many of your friends you have never met in the real world? & 9.77 & 10.057 \\
How many friends you meet regularly in the real world? & 8.42 & 13.917 \\
The number of hours I go on the web each day on average. & & \\
\hline
\end{tabular}

\section{Conclusions}

A study on student perception towards educational blogging was described. The following lists the conclusions of the study.

From the student perspective, the three main aspects of blogging purposes are personal, communication, and pedagogical. This is in agreement with our original analysis and the developed typology. There is a marked difference in the perception between the students who have had a year of experience with educational blogging and those without. Through the nature of the blogging tasks given, students have become aware of the purposes related to the blogging tasks. In our study, the blogging students have become more aware of the personal logbook purpose of weblogs. Most of the students are actively online and are accustomed to social life in the virtual world. However, the popularity of blogging among these students comes way behind other communication tools such as MSN/ICQ.

It must be noted that the student weblogs were deserted as soon as the course ended. The student weblogs were checked two weeks after the examination. None of the student weblogs had been updated for at least a month. Clearly, the students saw no purpose of continuing the blogging tasks. Williams and Jacobs (2004) concluded that it was a mistake to force the participation of students to blog with assessment, because it reduced the quality of the learning experience. This study however indicated that as long as students are blogging, there is a possibility that their perception can change according to the designed tasks.

Mandatory use of weblogs in a course is beneficial. It may be a long time before students are aware of the wonderful range of purpose afforded by weblogs. Still there are benefits in the incorporation of blogging in courses, albeit not necessarily direct educational benefits in related to the course. 


\section{Appendix: Questionnaire}

The following is the questionnaire for the students of MT356F. Questions in Q1 are left out of the questionnaire for the control group.

Q1. You have set up a blog for the course MT356F as required by part of the assessment. The above blog is the first blog I have ever set up.

Choose one from 1 to 5: 1 Strongly disagree; 2 Disagree; 3 Neutral; 4 Agree; 5 Strongly agree I regard the above blog as a log-book, where I store any data, information and thoughts. I regard the above blog as a diary of learning, where I keep personal reflections and feelings of the learning experience.

I regard the above blog as a place of dialog, where communication takes place.

I regard the above blog as a place of collaboration, where I work together with peer students. I regard the above blog as a source of information, where others obtain relevant information. I regard the above blog as a means of expressing myself, where I tell the world who I am. I regard the above blog as a place of file sharing, where electronic files are made available in the web. I regard the above blog as an electronic portfolio, where I purposely manage a collection of my representative work and ideas.

Q2.

Choose one from 1 to 4: 1 Always; 2 Sometimes; 3 Seldom; 4 Never

I go on the web for leisure and entertainment every day.

I go on the web for news and gossip every day.

I go on the web for academic information every day.

I use MSN/ICQ (or any messaging tool) every day.

I visit a discussion forum and read postings every day.

I visit a discussion forum and post messages every day.

Q3. Apart from the blog related to the course MT356F, do you own any personal blog(s) or personal diaries?

Choose one from the following

$1 \square$ Yes [Go to Question No.4]

$2 \square$ No, but I read and I want to set up a blog [Go to Question No.5]

$3 \square$ No, but I read blogs [Go to Question No.5] $4 \square$ No, I don't read and keep blogs. [Go to Question No.6]

Q4. How many personal blogs or online diaries do you own?

How many other blogs do you regularly visit (visit at least once every week)?

How many comments do you write to blogs per week?

How many postings do you write on your personal blog(s) per week?

In the following questions, use your own definition of a "friend".

How many friends you have made through blogging?

How many friends you have made through other web interaction (e.g., MSN/ICQ or web pages)?

How many of your friends you have never met in the real world?

How many friends you meet regularly in the real world?

Q5. The following questions are about your perception of blogging in general.

Choose from 1 to 5: 1 Strongly disagree; 2 Disagree; 3 Neutral; 4 Agree; 5 Strongly agree I regard blogging as a log-book, where I store any data, information and thoughts. I regard blogging as a diary of learning, where I keep personal reflections and feelings of the learning experience.

I regard blogging as a place of dialog, where communication takes place.

I regard blogging as a place of collaboration, where I work together with peer students. I regard blogging as a source of information, where others obtain relevant information. I regard blogging as a means of expressing myself, where I tell the world who I am. 
I regard blogging as a place of file sharing, where electronic files are made available in the web. I regard blogging as an electronic portfolio, where I purposely manage a collection of my representative work and ideas.

Q6.

$\begin{array}{ll}\text { Gender } & 1 \square \mathrm{M} \quad 2 \square \mathrm{F} \\ \text { Age } & \\ \text { Internet connectivity at home } & 1 \square \text { Broadband }(>10 \mathrm{M}) \\ & 2 \square \text { Broadband }(<=10 \mathrm{M}) \\ & 3 \square \text { Modem } \\ & 4 \square \text { None }\end{array}$

Choose from 1 to 5: 1 Strongly disagree; 2 Disagree; 3 Neutral; 4 Agree; 5 Strongly agree I am confident in managing my personal computer.

I am confident in using a computer to browse the web. I enjoy studying in groups or pairs.

I enjoy studying independently.

I enjoy the social life in the virtual world more than in the real world.

The virtual world interests me more than the real world.

The number of hours I go on the web each day on average.

\begin{tabular}{|c|c|c|c|c|}
\hline Father's level of education & $1 \square$ & $\begin{array}{l}\text { Primary school/Informal } \\
\text { education }\end{array}$ & $2 \square$ & Secondary school \\
\hline & $3 \square$ & $\begin{array}{l}\text { Matriculation/Tertiary } \\
\text { non-degree program } \\
\text { Others (Please specify): }\end{array}$ & $4 \square$ & Undergraduate/Postgraduate \\
\hline Mother's level of education & $\begin{array}{l}1 \square \\
3 \square \\
5 \square\end{array}$ & $\begin{array}{l}\text { Primary school/Informal } \\
\text { Education } \\
\text { Matriculation/Tertiary } \\
\text { non-degree program } \\
\text { Others (Please specify): }\end{array}$ & $2 \square$ & $\begin{array}{l}\text { Secondary school } \\
\text { Undergraduate/Postgraduate }\end{array}$ \\
\hline Types of residence & $\begin{array}{l}1 \square \\
3 \square\end{array}$ & $\begin{array}{l}\text { Public estate } \\
\text { Private housing }\end{array}$ & $\begin{array}{l}2 \square \\
4 \square\end{array}$ & $\begin{array}{l}\text { Home ownership scheme block } \\
\text { Others (Please specify): }\end{array}$ \\
\hline Monthly household income & $\begin{array}{l}1 \square \\
2 \square \\
3 \square \\
4 \square\end{array}$ & $\begin{array}{l}\text { Less than } \$ 10,000 \\
\$ 10.001-\$ 20,000 \\
\$ 20,001-\$ 30,000 \\
\$ 30,001-\$ 40,000\end{array}$ & $\begin{array}{l}5 \square \\
6 \square \\
7 \square \\
8 \square\end{array}$ & $\begin{array}{l}\$ 40,001-\$ 50,000 \\
\$ 50,001-\$ 60,000 \\
\$ 60,001-\$ 70,000 \\
\text { More than } \$ 70,001\end{array}$ \\
\hline
\end{tabular}

\section{References}

Berge, Z.L. (1995). Facilitating computer conferencing: Recommendations from the field. Educational Technology, 35(1), 22-30.

Blood, R. (2002). The Weblog Handbook: Practical Advice on Creating and Maintaining Our Blog. Perseus Publishing, Cambridge, Mass.

Cheung, M.Y., S.P.W. Shek, and C.L. Sia (2004). Virtual community of consumers: Why people are willing to contribute? In Proceedings of the 8th Pacific-Asia Conference on Information Systems (PACIS 2004), Shanghai, pp. 2100-2107.

Davis, F.D. (1989). Perceived usefulness, perceived ease of use, and user acceptance of information technology. MIS Quarterly 1989, 13(3), 319-340.

Davis, F.D. (1993). User acceptance of information technology: Systems characteristics, user perceptions and behavioral impacts. International Journal of Man-Machine Studies, 38(3), 475-487.

Downes, S. (2004). Educational Blogging, Educause Review, 39(5), 14-26. 
Efimova, L., and A. de Moor (2005). Beyond personal webpublishing: An exploratory study of conversational blogging practices. In Proceedings of the Hawaii International Conference on System Sciences (HICSS-38), IEEE Computer Society Press.

Efimova, L., and S. Hendrick (2005). In search for a virtual settlement: An exploration of weblog community boundaries. In Proceedings of 2nd International Conference on Communities and Technologies, Milano, Italy. Retrieved 9/5/2006 from

https://doc.telin.nl/dscgi/ds.py/Get/File-46041

Ferdig, R.E., and K.D. Trammell (2004). Content delivery in the Blogosphere. T.H.E. Journal, February. Retrieved 8/4/2006 from

ttp://www.thejournal.com/magazine/vault/articleprintversion. cfm?aid=4677

Fishbein, M., and I. Ajzen (1975). Belief, Attitude, Intention, and Behavior: An Introduction to Theory and Research. Addison-Wesley, Reading, MA.

Guidewire Group (2005). Blogging in the Enterprise - A Guidewire Group Market Cycle Survey. Retrieved $9 / 5 / 2006$ from

http: //www.guidewiregroup.com/site/pdf/CorporateBloggingSurvey.pdf

Herring, S.C. et al. (2005). Conversations in the blogosphere: An analysis "From the bottom up". In Proceedings of the 38th Hawaii International Conference on System Sciences (HICSS'05). IEEE Press, Los Alamos.

Huffaker, D. (2005). The educated blogger: Using weblogs to promote literacy in the classroom. AACE Journal, $13(2), 91-98$.

Hulsmann, T. (2003). Texts that talk back - asynchronous conferencing: A possible form of academic discourse? In U. Bernath and E. Rubin (Eds.), Reflections on Teaching and Learning in an Online Master Program. A Case Study, pp. 75-120.

Jacobs, J. (2003). Communication over rxposure: The rise of blogs as a product of cybervoyeurism. In C. Hatcher, J. Jacobs and T. Flew (Eds), Australian and New Zealand Communication Association Conference Proceedings, Brisbane. Retrieved 9/5/2006 from

http: //www.bgsb.qut. edu.au/conferences/ANZCA03/Proceedings/papers/ jjacobs_full.pdf

Knobel, M., and C. Lankshear (2003). Do-it-yourself broadcasting: Writing weblogs in a knowledge society. Paper presented at the AERA, Chicago. Retrieved 10/4/2006 from uob-community.ballarat.edu.au/ clankshear/blog_paper_vfinal.doc

Lampa, G. (2004). Imagining the blogosphere: An introduction to the imagined community of instant publishing. In L.J. Gurak, S. Antonijevic, L. Johnson, C. Ratliff, and J. Reyman (Eds.), Into the Blogosphere: Rhetoric, Community, and Culture of Weblogs. Retrieved 8/5/2006 from

http://blog.lib.umn.edu/blogosphere/imagining_the_blogosphere.html

Marlow, C. (2004). Audience, structure and authority in the weblog community. Paper presented at the International Communication Association Conference, New Orleans, LA. Retrieved 9/5/2006 from http://alumni.media.mit.edu/ cameron/cv/pubs/04-01.pdf

Mejias, U. (2004). Distributed textual discourse: A new approach to online discourse. Ideant, August 16. Retrieved 8/5/2006 from http: //ideant.typepad.com/ideant/2004/08/distributed_tex.html

O’Donnell, M. (2005). Blogging as pedagogic practice: Artefact and ecology. Blog Talk Downunder, Sydney, Australia.

O’Malley, J., and H. McCraw (1999a). Students' perceptions of distance learning, online learning, and the traditional classroom. Online Journal of Distance Learning Administration, 2(4)

O’Malley, J., and H. McCraw (1999b). Students' perceptions of distance learning, online learning, and the traditional classroom. Online Journal of Distance Learning Administration, 2(4). Retrieved 10/4/2006 from www. westga. edu/ distance/omalley24.html.

Perseus Development Corp. (2003). The blogging iceberg. Perseusdevelopment.com. Retrieved 9/5/2006 from http: //www.perseusdevelopment.com/blogsurvey

Preece, J., B. Nonnecke and D. Andrews (2004). The top 5 reasons for lurking: Improving community experiences for everyone. Computers in Human Behavior, 2(1).

Rainie, L., S. Fox, and M. Madden (2002). One year later: September 11 and the Internet. Pew Internet and Americal Life Project. Retrieved 8/5/2005 from http: //www.pewinternet.org/reports/pdfs/PIP_9-11_Report.pdf.

Röll, M. (2004). Distributed KM - Improving knowledge workers' productivity and organisational knowledge 
sharing with weblog-based personal publishing. Paper presented at BlogTalk 2.0 - The European Conference on Weblogs, Vienna.

Stiler, G.M., and T. Phillko (2003). Blogging and blogspots: An alternative format for encouraging reflective practice among preservice teachers. Education, 123(4), 789.

Stoffregen, T.A. (2003). Affordances are enough: Reply to Chemero et al. (2003). Ecological Psychology, 15(1), 29-36.

Tosh, D., and B. Werdmuller (2004). ePortfolios and Weblogs: One vision for ePortfolio development. ePortfolio Research and Development Community. Retrieved 8/4/2006 from

http://www.eradc.org/papers/ePortfolio_Weblog.pdf

Wagner, C. (2003). Put another (B)log on the wire: Publishing learning logs as weblogs. Journal of Information Systems Education, 14(2), 131-132.

Williams, J.B., and J. Jacobs (2004). Exploring the use of Blogs as learning spaces in the higher education sector. Australasian Journal of Educational Technology, 20(2), 232-247.

Wozniak, H., and S. Silveira (2004). Online discussions: Promoting effective student-to-student interaction. In R. Atkinson, C. McBeath, D. Jonas-Dwyer and R. Phillips (Eds.), Beyond the Comfort Zone: Proceedings of the 21st ASCILITE Conference, Perth, pp. 956-960. Retrieved 8/4/2006 from

http://www.ascilite.org.au/conferences/perth04/procs/wozniak.html

Wrede, O. (2003). Weblogs and discourse: Weblogs as a transformational technology for higher education and academic research. Blogtalk Conference Paper, Vienna.

Wu, D., and S.R. Hiltz (2004). Predicting learning from asynchronous online discussions. Journal of Asynchronous Learning Networks, 8(2), 139-152. 
A.K. Lui is an assistant professor in the School of Science and Technology, the Open University of Hong Kong. Lui received his Doctor of Philiosophy from the Australian National University, Canberra. His research interests include social computing, intelligent tutoring systems, and Internet computing.

S.O. Choy is a lecturer in the School of Science and Technology, the Open University of Hong Kong. Choy received his Bachelor of Engineering with honors and Doctor of Philosophy from the Hong Kong Polytechnic University. His research interests include digital image processing, software engineering, distributed computing, and Internet computing. Choy's recent works involved investigating innovative ways in which technologies can be most appropriately applied in the service of education.

Y.H.Y. Cheung is a PhD student at the Department of Sociology, The Chinese University of Hong Kong. She earned her first degree from the Australian National University, specializing in Sociology of Education. Her research interests include Sociology of Education, Organizations, and Social Research Methods.She is working on her PhD dissertation, "The Embeddedness of Educational Reform: A Study of University Reform in Asia".

S.C. Li received a BSc(Hons) in 1984 from the University of Hong Kong and Postgraduate Certificate in Education in subsequent years from the same university. He received his Ph.D. in theoretical nuclear and particle physics in 1996 from the Australian National University. He was a secondary school teacher in Hong Kong for eight years before pursuing his PhD degree. He was a postdoctoral research fellow in ANU, working in the area of computer simulation and modelling of protein dynamics. He subsequently joined the Centre for Information Technology in Education of the Faculty of Education of the University of Hong Kong as the deputy director from 1998-2001. He is currently an associate professor and also the course coordinator of the full-time Postgraduate Diploma in Education programme. He has been the principal investigator of a number of research projects in the area of IT in education, funded by the Competitive Earmarked Research Grant Committee and the HKSAR government. 


\title{
Studentu švietimui skirtu internetiniu dienoraščiu isisavinimo tyrimas
}

\author{
Andrew K. LUI, Sheung-On CHOY, Yannie H.Y. CHEUNG, Sandy C. LI
}

Internetiniai dienoraščiai yra populiari ir lengva naudoti asmeninès saviraiškos internete forma, leidžianti milijononams interneto naudotoju reikšti savo mintis, nuomones bei tobulinti savo žiniatinklio naudojimo igūdžius. Internetiniu dienoraščiu, kaip universalios priemonès, ivvairiapusiškumas susilaukia dẻstytojų bei pedagogu dèmesio. Iki šiol internetiniuose dienoraščiuose pateikiama mokomoji medžiaga apėmè žurnalus, elektroninius aplankus (e-portfolio), pažymiu knygeles, darbo žurnalus. Panašiai kaip ir kitu švietimo technologiju atveju, studentu supratimas yra lemiamas veiksnys siekiant įvertinti, ar internetiniai dienoraščiai yra švietimo požiūriu naudojami rezultatyviai. Straipsnyje nagrinejjama, kaip studentai supranta internetinių dienoraščiu tikslus. Supažindinama su patirtimi, igyta pateikiant trečiojo kurso informatikos specialybės studentams užduotis, susijusias su internetiniais dienoraščiais, bei lyginant šių studentu supratimą apie internetinius dienoraščius su kitų studentu, neturèjusių panašių užduočių, požiūriu. Siekiant paaiškinti šiuos internetinių dienoraščiu suvokimo skirtumus pristatomas studentų percepcijos modelis. Pateikiama išvada, jog internetinių dienoraščiu ịtraukimas ị privalomają mokymo programą palaipsniui gali pasitarnauti, siekiant edukaciniu požiūriu brandaus studentų išmanymo apie šią sritị. 